\title{
Can simple models predict large-scale surface ocean isoprene concentrations?
}

\author{
Dennis Booge ${ }^{1}$, Christa A. Marandino ${ }^{1}$, Cathleen Schlundt ${ }^{1}$, Paul I. Palmer ${ }^{2}$, Michael Schlundt ${ }^{1}$, Elliot L. Atlas ${ }^{3}$, \\ Astrid Bracher ${ }^{4,5}$, Eric S. Saltzman ${ }^{6}$, and Douglas W. R. Wallace ${ }^{7}$ \\ ${ }^{1}$ GEOMAR Helmholtz Centre for Ocean Research Kiel, Kiel, Germany \\ ${ }^{2}$ School of GeoSciences, University of Edinburgh, Edinburgh, UK \\ ${ }^{3}$ Rosenstiel School of Marine and Atmospheric Science (RSMAS), University of Miami, Miami, FL, USA \\ ${ }^{4}$ Alfred Wegener Institute - Helmholtz Centre for Polar and Marine Research, Bremerhaven, Germany \\ ${ }^{5}$ Institute of Environmental Physics, University Bremen, Bremen, Germany \\ ${ }^{6}$ Department of Earth System Science, University of California, Irvine, CA, USA \\ ${ }^{7}$ Department of Oceanography, Dalhousie University, Halifax, Canada
}

Correspondence to: Dennis Booge (dbooge@geomar.de)

Received: 2 June 201 - Published in Atmos. Chem. Phys. Discuss.: 22 June 2016

Revised: 26 August 2016 - Accepted: 5 September 2016 - Published: 22 September 2016

\begin{abstract}
We use isoprene and related field measurements from three different ocean data sets together with remotely sensed satellite data to model global marine isoprene emissions. We show that using monthly mean satellite-derived chl $a$ concentrations to parameterize isoprene with a constant chl $a$ normalized isoprene production rate underpredicts the measured oceanic isoprene concentration by a mean factor of $19 \pm 12$. Improving the model by using phytoplankton functional type dependent production values and by decreasing the bacterial degradation rate of isoprene in the water column results in only a slight underestimation (factor $1.7 \pm 1.2$ ). We calculate global isoprene emissions of $0.21 \mathrm{Tg} \mathrm{C}$ for 2014 using this improved model, which is twice the value calculated using the original model. Nonetheless, the sea-to-air fluxes have to be at least 1 order of magnitude higher to account for measured atmospheric isoprene mixing ratios. These findings suggest that there is at least one missing oceanic source of isoprene and, possibly, other unknown factors in the ocean or atmosphere influencing the atmospheric values. The discrepancy between calculated fluxes and atmospheric observations must be reconciled in order to fully understand the importance of marine-derived isoprene as a precursor to remote marine boundary layer particle formation.
\end{abstract}

\section{Introduction}

Remote marine boundary layer aerosol and cloud formation is important for both the global climate system/radiative budget and for atmospheric chemistry (Twomey, 1974) and has been investigated, with contentious results, for decades. The question remains: what are the precursors to aerosol and cloud formation over the ocean? Earlier studies pinpointed dimethyl sulfide (DMS) as the main precursor, as described in the CLAW hypothesis (Charlson et al., 1987). More recently, this hypothesis has been debated controversially (Quinn and Bates, 2011) because primary organic aerosols (POA; O'Dowd et al., 2008) and small sea salt particles (Andreae and Rosenfeld, 2008; de Leeuw et al., 2011) have been identified as cloud condensation nuclei $(\mathrm{CCN})$ precursors with higher CCN production potential than DMS. In addition to POA, other gases besides DMS have been hypothesized as important for remote marine secondary organic aerosol formation (SOA), including isoprene (2-methyl-1,3butadiene), which has received the most attention in recent years (Carlton et al., 2009).

Isoprene is a byproduct of plant metabolism and one of the most abundant of the atmospheric volatile non-methane hydrocarbons (NMHC). On a global basis, as much as $90 \%$ of atmospheric isoprene comes from terrestrial plant emissions (400-600 Tg C yr ${ }^{-1}$; Guenther et al., 2006; Arneth et al., 2008). Isoprene is very short lived in the atmosphere, with 
a lifetime ranging from minutes to a few hours. The principal loss mechanism is reaction with hydroxyl radicals $(\mathrm{OH})$, but reactions with ozone and nitrate radicals are also important sinks (Atkinson and Arey, 2003; Lelieveld et al., 2008).

The importance of the ocean as a source of atmospheric isoprene is unclear, as only few studies have directly measured isoprene concentrations in the euphotic zone. Throughout most of the world oceans, near-surface seawater isoprene concentrations range between $<1$ and $200 \mathrm{pmol} \mathrm{L}^{-1}$, depending on season and region (Bonsang et al., 1992; Milne et al., 1995; Broadgate et al., 1997; Baker et al., 2000; Matsunaga et al., 2002; Broadgate et al., 2004; Zindler et al., 2014; Ooki et al., 2015). Higher isoprene levels have been measured in Southern Ocean and Arctic waters (395 and $541 \mathrm{pmol} \mathrm{L}^{-1}$, respectively; Kameyama et al., 2014; Tran et al., 2013). Atmospheric isoprene levels can be as high as 300 parts per trillion (ppt), varying with location and time of day (Shaw et al., 2010). Generally, the mixing ratios are lower than $100 \mathrm{ppt}$ in remote areas not influenced by terrestrial sources (Yokouchi et al., 1999), but they can also increase up to $375 \mathrm{ppt}$ during a phytoplankton bloom (Yassaa et al., 2008). Matsunaga et al. (2002) found that the sea-toair flux estimated from measurements could not explain the atmospheric concentrations observed in the western North Pacific. This agrees with the model calculations of $\mathrm{Hu}$ et al. (2013), who found that top-down and bottom-up models estimating isoprene emissions disagree by 2 orders of magnitude.

Assessing the importance of isoprene for marine atmospheric chemistry and SOA formation requires extrapolations of measurements to develop global emissions climatologies and inventories. Model studies suggest that oceanic sources of isoprene are too weak to control marine SOA formation (Spracklen et al., 2008; Arnold et al., 2009; Gantt et al., 2009; Anttila et al., 2010; Myriokefalitakis et al., 2010) and field studies indicate that the organic carbon (OC) contribution from oceanic isoprene is less than $2 \%$ and out of phase with the peak of OC in the Southern Indian Ocean (Arnold et al., 2009). In contrast, Hu et al. (2013) found that, despite sometimes low isoprene fluxes calculated by models, oceanic isoprene emissions can increase abruptly in association with phytoplankton blooms, resulting in regionally and seasonally important isoprene-derived SOA formation. Further experiments showed that isoprene oxidation products can increase the level of $\mathrm{CCN}$ when the number of CCN is low (Ekström et al., 2009). Lana et al. (2012) used both model-calculated fluxes of isoprene and remote sensing products to investigate isoprene-derived SOA formation in the marine atmosphere. Their results illustrated that the oxidation products of marine trace gases seemed to influence the condensation growth and the hygroscopic activation of small primary particles. Fluxes of isoprene (and other marine-derived trace gases) showed greater positive correlations with $\mathrm{CCN}$ number and greater negative correlations with aerosol effective radius than POA and sea salt over most of the world's oceans.

Since isoprene concentration measurements from the open ocean are sparse, it is essential to combine laboratory and field measurements, remote sensing, and modeling if we want to understand marine isoprene emissions. This study utilizes measurements of surface ocean isoprene and associated biological and physical parameters on three oceanographic cruises to refine and validate the model of Palmer and Shaw (2005) for estimating marine isoprene concentrations and emissions. The resulting model, with satellite-derived input, is used to compute monthly climatologies and annual average estimates of isoprene in the world ocean.

\section{Methods}

\subsection{Model description}

In this study we use a simple steady-state model for surface ocean isoprene consisting of a mass balance between biological production, chemical and biological losses, and emission to the atmosphere (Palmer and Shaw, 2005):

$$
\begin{aligned}
& P-C_{\mathrm{W}}\left(\sum k_{\mathrm{CHEM}, i} C_{X i}+k_{\mathrm{BIOL}}+\frac{k_{\mathrm{AS}}}{\mathrm{MLD}}\right) \\
& -L_{\mathrm{MIX}}=0,
\end{aligned}
$$

where biological production $(P)$ is balanced by all loss processes, $C_{\mathrm{W}}$ is the seawater concentration of isoprene, $k_{\mathrm{CHEM}}$ is the chemical rate constant for all possible loss pathways $(i)$ with all reactants $(X)\left(X=\mathrm{OH}\right.$ and $\left.\mathrm{O}_{2}\right), k_{\mathrm{BIOL}}$ is the biological loss rate constant, which takes into account the biodegradation of isoprene, $k_{\mathrm{AS}}$ is the air-sea gas transfer coefficient that considers the loss processes due to air-sea gas exchange scaled with the depth of the ocean mixed layer (MLD), and $L_{\text {MIX }}$ is the loss due to physical mixing (Table 1). The model equation was rearranged to solve for $C_{\mathrm{W}}$ (Eq. 2) as follows:

$C_{\mathrm{W}}=\frac{P-L_{\mathrm{MIX}}}{\sum k_{\mathrm{CHEM}, i} C_{X i}+k_{\mathrm{BIOL}}+\frac{k_{\mathrm{AS}}}{\mathrm{MLD}}}$.

The air-sea flux of isoprene $(F)$ was calculated using the equation

$F=k_{\mathrm{AS}}\left(C_{\mathrm{W}}-C_{\mathrm{A}} / K_{\mathrm{H}}\right)=\sim k_{\mathrm{AS}}\left(C_{\mathrm{W}}\right)$,

where $C_{\mathrm{A}}$ is the air-side concentration of isoprene and $K_{\mathrm{H}}$ is the dimensionless form of the Henry's law constant (equilibrium ratio of $C_{\mathrm{A}}$ and $\left.C_{\mathrm{W}}\right) . C_{\mathrm{A}}$ is assumed to be negligible compared to $C_{\mathrm{W}}$ as noted above (Eq. 3). As a result, the airsea isoprene gradient is assumed equal to the surface ocean isoprene level, and emissions are assumed to be first order in $C_{\mathrm{W}}$. This assumption is justified over the open ocean because of the short atmospheric lifetime of isoprene. In coastal regions downwind of strong isoprene sources, this assumption 
Table 1. List of parameters used in each model.

\begin{tabular}{|c|c|c|c|c|c|}
\hline \multirow[t]{2}{*}{ Parameter } & \multirow[t]{2}{*}{ Abbreviation } & \multirow[t]{2}{*}{ Unit } & \multicolumn{3}{|c|}{ Model approach } \\
\hline & & & ISOPS05 & ISOPFT & $\mathrm{ISO}_{\mathrm{PFT}-k_{\mathrm{BIO}}}$ \\
\hline Isoprene production rate & $P$ & pmol L ${ }^{-1}$ day $^{-1}$ & $P_{\text {chloro }} \times[\operatorname{chl} a]$ & $P_{\text {chloro }} \times[\mathrm{PFT}]$ & $P_{\text {chloro }} \times[\mathrm{PFT}]$ \\
\hline \multirow[t]{2}{*}{ Chemical loss rate } & $k_{\mathrm{OH}} \times C_{\mathrm{OH}}$ & day $^{-1}$ & 0.0518 & 0.0518 & 0.0518 \\
\hline & $k_{\mathrm{O}_{2}} \times C_{\mathrm{O}_{2}}$ & day $^{-1}$ & 0.0009 & 0.0009 & 0.0009 \\
\hline Biological loss rate & $k_{\mathrm{BIOL}}$ & day $^{-1}$ & 0.06 & 0.06 & 0.01 \\
\hline Gas transfer coefficient & $k_{\mathrm{AS}}$ & $\mathrm{m} \mathrm{s}^{-1}$ & \multicolumn{3}{|c|}{ Wanninkhof (1992) } \\
\hline Mixed layer depth & MLD & $\mathrm{m}$ & \multicolumn{3}{|c|}{ de Boyer Montégut et al. (2004) } \\
\hline Mixing loss rate & $L_{\mathrm{MIX}}$ & pmol L ${ }^{-1}$ day $^{-1}$ & 0.0459 & 0.0459 & 0.0459 \\
\hline $\begin{array}{l}\text { Chl } a \text { normalized } \\
\text { isoprene production rate }\end{array}$ & $P_{\text {chloro }}$ & $\mu \mathrm{mol}(\mathrm{g} \operatorname{chl} a)^{-1} \mathrm{day}^{-1}$ & 1.8 & \multicolumn{2}{|c|}{ PFT dependent (Table 2) } \\
\hline
\end{tabular}

may not be valid. The air-sea exchange transfer coefficient $\left(k_{\mathrm{AS}}\right)$ is computed using the Wanninkhof (1992) wind-speedbased $\left(U_{10}\right)$ parameterization and the Schmidt number $S_{C}$ of isoprene (Palmer and Shaw, 2005):

$k_{\mathrm{AS}}=0.31 U_{10}^{2}\left(\frac{S_{C}}{660}\right)^{-0.5}$

Further details about the rate constants and input parameters are described in Table 1 . Monthly mean wind speed $\left(U_{10}\right)$ and sea surface temperature (SST) were obtained from the Quick Scatterometer (QuickSCAT) satellite and the Moderate Resolution Imaging Spectroradiometer (MODIS) instrument on board the Aqua satellite, respectively, and from in situ shipboard measurements. MLDs were obtained from climatological monthly means (de Boyer Montégut et al., 2004) and compared to those calculated by in situ conductivity, temperature, and depth (CTD) profile measurements during each cruise. MLD was defined as the depth at which temperature is at least $0.2^{\circ} \mathrm{C}$ higher or lower than the temperature at $10 \mathrm{~m}$ depth (de Boyer Montégut et al., 2004). Chlorophyll $a$ (chl $a$ ) concentrations were obtained either from the MODIS instrument on board the Terra satellite or from in situ shipboard measurements (here chl $a$ is defined as the sum of monovinyl chl $a$, divinyl chl $a$, and chlorophyllide $a$ ). Model calculations were carried out using MATLAB (Mathworks).

The steady-state model assumption is justified by the relatively short lifetime of isoprene in seawater as air-sea exchange is the dominant loss term over all latitudes and seasons (lifetime: $7-14$ days) followed by $k_{\mathrm{BIOL}}$ and $k_{\mathrm{CHEM}}$ (Palmer and Shaw, 2005). In this study, model runs were carried out using three different sets of model parameters (Table 1).

1. ISOPS05: the original configuration used by Palmer and Shaw (2005). In this configuration, the production of isoprene is parameterized as the product of the bulk chl $a$ concentration and a chl $a$ normalized isoprene production rate $\left(P_{\text {chloro }}\right)$ inferred from laboratory phytoplankton monocultures of several cyanobacteria, eu- karyotes, and coccolithophores (Shaw et al., 2003). This approach inherently assumes that all phytoplankton have the same isoprene production characteristics. Palmer and Shaw (2005) also assumed that biological degradation of isoprene occurs in the water column, based on indirect evidence of a biological sink for isoprene (Moore and Wang, 2006), but no isoprene loss rate constants have been published to date. They assumed a global average lifetime of $\sim 17$ days $\left(k_{\mathrm{BIOL}}=\right.$ 0.06 day $^{-1}$ ) based on the biological degradation rates of different data sets of methyl bromide (Tokarczyk et al., 2003; Yvon-Lewis et al., 2002).

2. ISO PFT $_{\text {: different }} P_{\text {chloro }}$ values are applied for different phytoplankton functional types (PFTs). Laboratory studies have shown that isoprene production rates vary significantly across different PFTs (Bonsang et al., 2010; Colomb et al., 2008; Exton et al., 2013; Shaw et al., 2003; Arnold et al., 2009). We use the PFTdependent isoprene production rate constants and field observations of PFT distributions to estimate isoprene production rates. The chl $a$ normalized isoprene production rates of the different algae species are averaged within each PFT to obtain an estimated $P_{\text {chloro }}$ value of isoprene for each PFT. PFT distributions along our cruise tracks were derived from the soluble organic pigment concentrations obtained from filtered water samples through Whatman GF/F filters using highpressure liquid chromatography (HPLC) according to the method of Barlow et al. (1997). This method was adjusted to our temperature-controlled instruments as detailed in Taylor et al. (2011a). We determined the list of pigments shown in Table 2 of Taylor et al. (2011a) and applied the method of Aiken et al. (2009) for quality control of the pigment data. Pigment data from expedition ANT-XXV/1 have been already published in Taylor et al. (2011a). From the HPLC pigment concentration we calculated PFT groups using the diagnostic pigment (DP) analysis developed by Vidussi et 
al. (2001) and adapted in Uitz et al. (2006) to relate the weighted sum of seven, for each PFT representative DP. Using this approach, the chl $a$ concentrations for diatoms, dinoflagellates, haptophytes, chrysophytes, cryptophytes, cyanobacteria (excluding prochlorophytes), and chlorophytes were derived. The chl $a$ concentration of prochlorophytes was derived directly from the divinyl-chl $a$ concentration (the marker pigment for this group).

3. ISO $_{\mathrm{PFT}-k_{\mathrm{BIO}}}$ : the PFT approach is utilized to parameterize isoprene production as in ISOPFT and assumes that biological losses of isoprene in the water column are significantly slower than assumed by Palmer and Shaw (2005). Seawater incubation experiments carried out in temperature-controlled water baths over periods ranging from 48 to $72 \mathrm{~h}$ under natural light conditions, using deuterated isoprene (isoprene-d5), showed significantly longer lifetimes (manuscript in preparation).

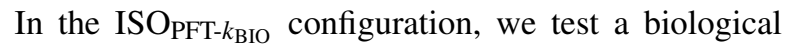
degradation lifetime of minimum 100 days $\left(k_{\mathrm{BIOL}}=\right.$ 0.01 day $^{-1}$ ).

\subsection{Cruise tracks}

Isoprene was measured in the surface seawater during three separate cruises: the ANT-XXV/1 in the eastern Atlantic Ocean, the SPACES/OASIS cruises in the Indian Ocean, and the ASTRA-OMZ cruise in the eastern Pacific Ocean. ANT-XXV/1 took place in November 2008 on board the R/V Polarstern from Bremerhaven, Germany, to Cape Town, South Africa (Fig. 1; for details about isoprene and ancillary data see also Zindler et al., 2014). The SPACES/OASIS cruises took place in June-July 2014 on board the R/V Sonne from Durban, South Africa, via Port Louis, Mauritius, to Malé, Maldives, and the ASTRA-OMZ cruise took place in October 2015 on board the R/V Sonne from Guayaquil, Ecuador, to Antofagasta, Chile (Fig. 1). Air mass backward trajectories $(12 \mathrm{~h}$; starting altitude: $50 \mathrm{~m})$ from the Hybrid Single-Particle Lagrangian Integrated Trajectory (HYSPLIT; http://www.arl.noaa.gov/HYSPLIT.php) model were calculated for the sampling sites. The trajectories, in combination with atmospheric measurements, suggest that the air masses encountered on these cruises were from over the ocean for more than $12 \mathrm{~h}$ prior to sampling and are therefore unlikely to contain significant isoprene derived from terrestrial sources (Fig. 1).

\subsection{Isoprene measurements}

\subsubsection{Eastern Atlantic Ocean}

The isoprene measurements from the ANT-XXV/1 (November 2008, eastern Atlantic Ocean) cruise are described in detail in Zindler et al. (2014). Seawater from approximately
$2 \mathrm{~m}$ depth was continuously pumped on board and flowed through a porous Teflon membrane equilibrator. Isoprene was equilibrated by using a counterflow of dry air and was measured using an atmospheric pressure chemical ionization mass spectrometer (mini-CIMS), which consists of a ${ }^{63} \mathrm{Ni}$ atmospheric pressure ionization source coupled to a single quadrupole mass analyzer (Stanford Research Systems, SRS RGA200). Isoprene from a standard tank was added to the equilibrated air stream every $12 \mathrm{~h}$ to calibrate the system. The precision for isoprene measurements was $\pm 13 \%$. The isoprene data used here are 5 min averages.

\subsubsection{Indian and eastern Pacific Oceans}

The isoprene measurements on the SPACES/OASIS (JuneJuly 2014, Indian Ocean) and ASTRA-OMZ (October 2015, eastern Pacific Ocean) cruises have not been published previously. Water samples $(50 \mathrm{~mL})$ were taken every $3 \mathrm{~h}$ from a continuously running seawater pump system located in the ship's moon pool at approximately $6 \mathrm{~m}$ depth. All samples were analyzed on board within 15 min of collection using a purge and trap system attached to a gas chromatograph/mass spectrometer operating in single ion mode (GC/MS; Agilent 7890A/Agilent 5975C; inert XL MSD with triple axis detector). Isoprene was purged from the water sample with helium for $15 \mathrm{~min}$ and dried using a Nafion membrane dryer (Perma Pure; ASTRA-OMZ) or potassium carbonate (SPACES/OASIS). Before being injected into the GC, isoprene was preconcentrated in a trap cooled with liquid nitrogen. Gravimetrically prepared liquid standards in ethylene glycol were measured in the same way as the samples and used to perform daily calibrations for quantification. Gaseous deuterated isoprene (isoprene-d5) was measured together with each sample as an internal standard to account for possible sensitivity drift between calibrations. The precision for isoprene measurements was $\pm 8 \%$.

Air samples were collected in electropolished stainless steel flasks and pressurized to approximately 2.5 atm with a metal bellows pump. Analysis was conducted after samples were returned to the laboratory. Isoprene was measured along with a range of halocarbons, hydrocarbons, and other gases using a combined GC/MS/FID/ECD system with a modified Markes Unity II/CIA sample preconcentrator. The modifications incorporated a water removal system consisting of a cold trap $\left(-20^{\circ} \mathrm{C}\right)$ and a Perma Pure dryer (MD-050-24). Isoprene and $>\mathrm{C} 4$ hydrocarbons were quantified using selected ion MS and were calibrated against a whole air sample that is referenced to a NIST hydrocarbon mixture using GC/FID. Precision for isoprene is estimated at approximately $\pm 0.4 \mathrm{ppt}+5 \%$. 


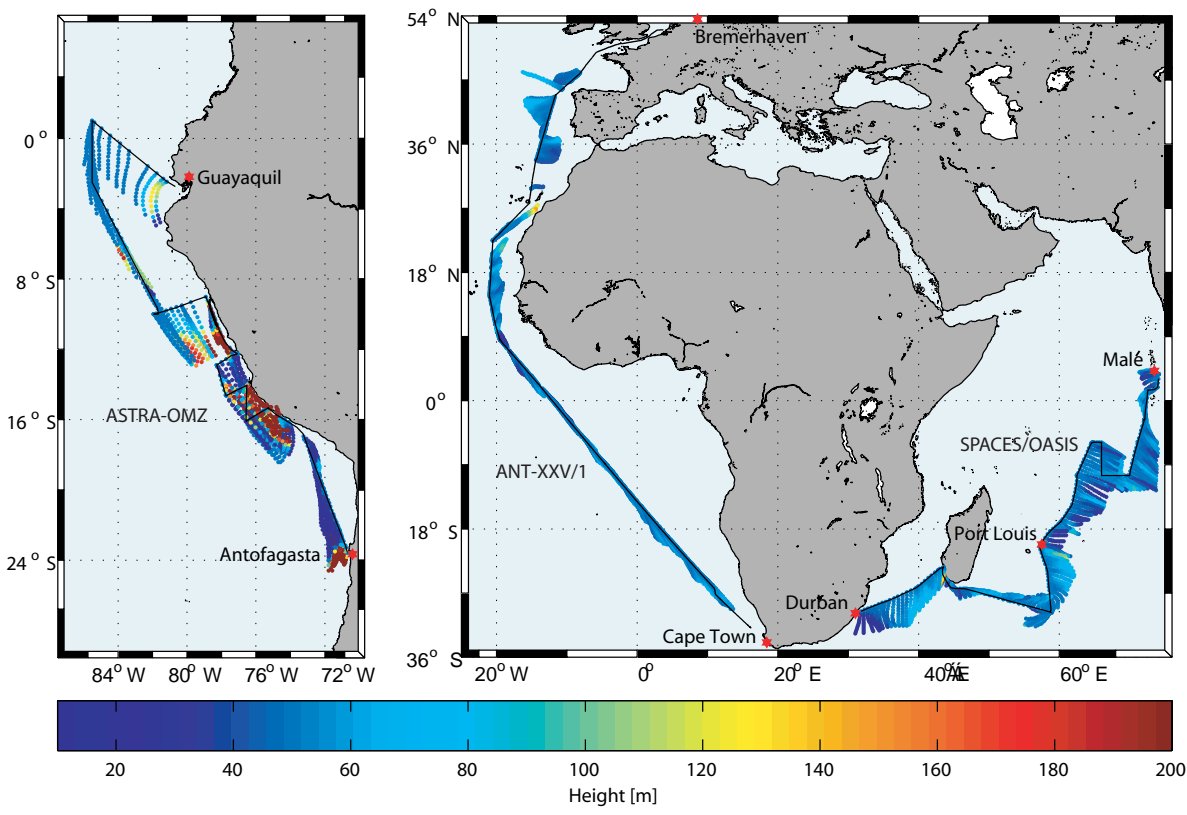

Figure 1. Cruise tracks (black) of ANT-XXV/1 (November 2008, eastern Atlantic Ocean), SPACES/OASIS (June-July 2014, Indian Ocean) and ASTRA-OMZ (October 2015, eastern Pacific Ocean). Air mass back trajectories calculated for $12 \mathrm{~h}$ with a starting height of $50 \mathrm{~m}$ using HYSPLIT are superimposed on the cruise track. Color coding indicates altitude above sea level.

\section{Results and discussion}

\subsection{Comparison of modeled and in situ measured isoprene data}

The shipboard isoprene measurements from the ANT-XXV/1 cruise ranged from 2 to $157 \mathrm{pmol} \mathrm{L}^{-1}$, with the highest levels in the subtropics of the Southern Hemisphere and lower levels in the tropics (Fig. 2). Model simulations were carried out along the cruise track using monthly mean satellite data from November 2008 for chl $a$, surface winds, SST, and MLD as input parameters. The simulations underestimated the measured isoprene concentrations significantly, by as much as a factor of 20 over most of the cruise track (mean error of $19.1 \mathrm{pmol} \mathrm{L}^{-1}$ ). Simulations were also carried out using in situ shipboard measurements (chl $a$, wind speed, SST, MLD) as the input parameters. In both cases, the model simulations show a peak in the calculated isoprene levels at $13-17^{\circ} \mathrm{N}$ which is not present in the observations, whereas the peak, using in situ data as input parameter, is much smaller. This peak corresponds to elevated chl $a$ concentrations, suggesting that while there may have been high biological activity in this region, isoprene-producing species were not abundant (Figs. 3, 4). These results demonstrate that a single isoprene production factor and bulk chl $a$ concentration do not adequately describe the variability in isoprene production. When isoprene-producing PFTs are dominant, however, the modeled isoprene values follow the observed isoprene values (increasing isoprene concentration north of $33^{\circ} \mathrm{N}$; Figs. 2, 5).
The elevated isoprene concentrations in the subtropics of the Southern Hemisphere are not represented by the model.

Monthly mean satellite data cannot resolve rapid changes like short phytoplankton blooms or wind events. We compared the satellite data to the ship's in situ measurements of SST, wind speed, calculated MLD, and in situ measured chl $a$ concentration as input parameters for the model (Fig. 3) in order to determine if the resolution of the satellite data does resolve important features. The modeled isoprene concentrations closely follow the variability in chl $a$, demonstrating that chl $a$ has the strongest influence of the four input parameters to the model. The differences between modeled isoprene concentrations using in situ data vs. satellite data are due primarily to the differences in chl $a$ (in situ data are in general 2 times higher than satellite data) with the largest differences in the regions from $10-25$ to $40-45^{\circ} \mathrm{N}$. As the discrepancies between in situ and satellite data are significant, in situ measured data of chl $a$ are used from now on for further calculations with the ISOPS05 model. Using monthly mean satellite data for wind speed, SST, and climatological values for MLD does not bias the model results significantly relative to the in situ data. Eight-day mean chl $a$ and weekly wind speed satellite data (not shown) are also available and could lower the discrepancies to the in situ data. For this study, 8day values were not useful for this region and time due to cloud coverage (loss of $46 \%$ of data points). A compromise between the two would be to average the 8-day values over a larger area grid to increase the amount of satellite-derived data, but this would lower the resolution and therefore the accurate comparison with the cruise track. 


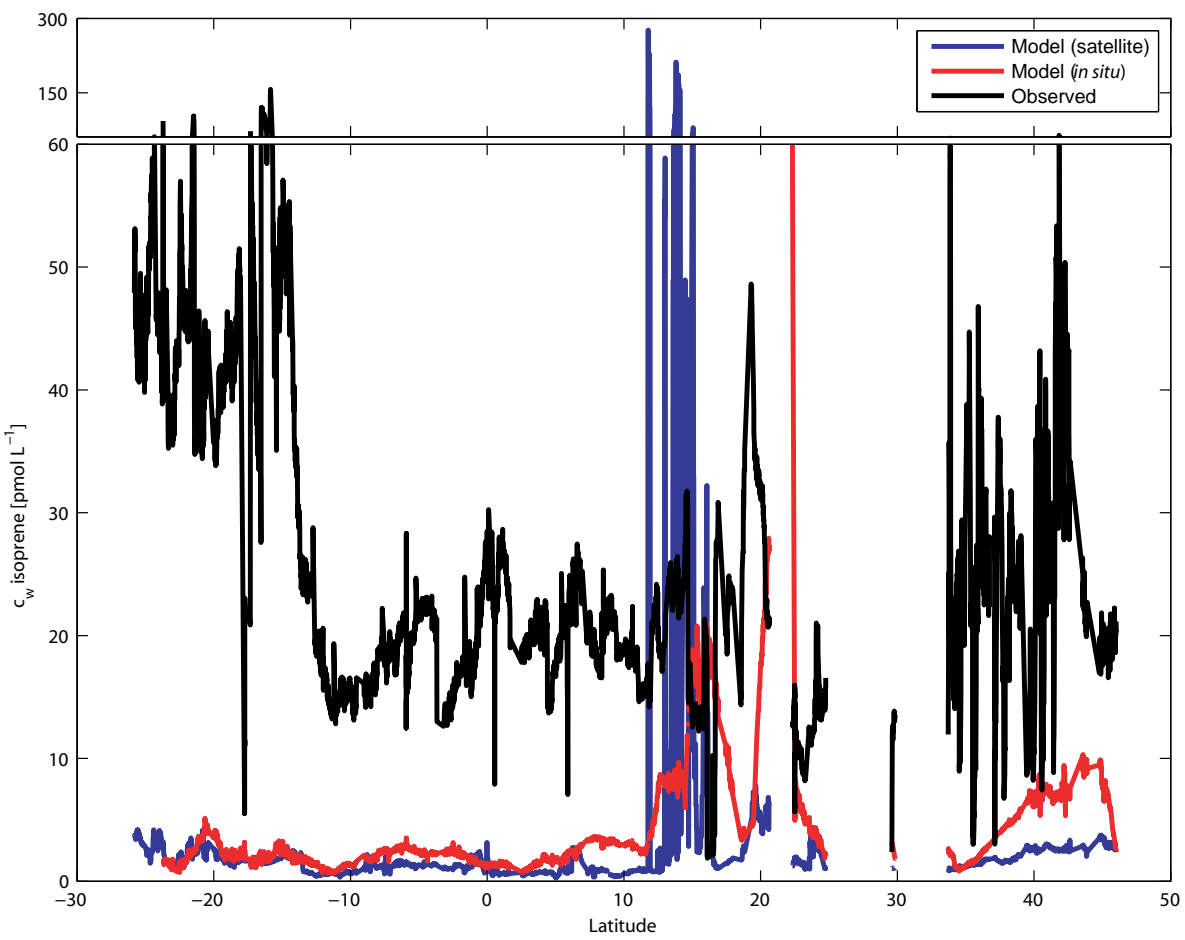

Figure 2. Comparison of observed (black) and modeled seawater isoprene concentrations for the ANT-XXV/1 cruise. Model calculations were carried out using the ISOPS05 model configuration, with monthly mean satellite data (blue) for chl $a$, wind speed, SST, and MLD (climatology) and in situ shipboard measurements (red).
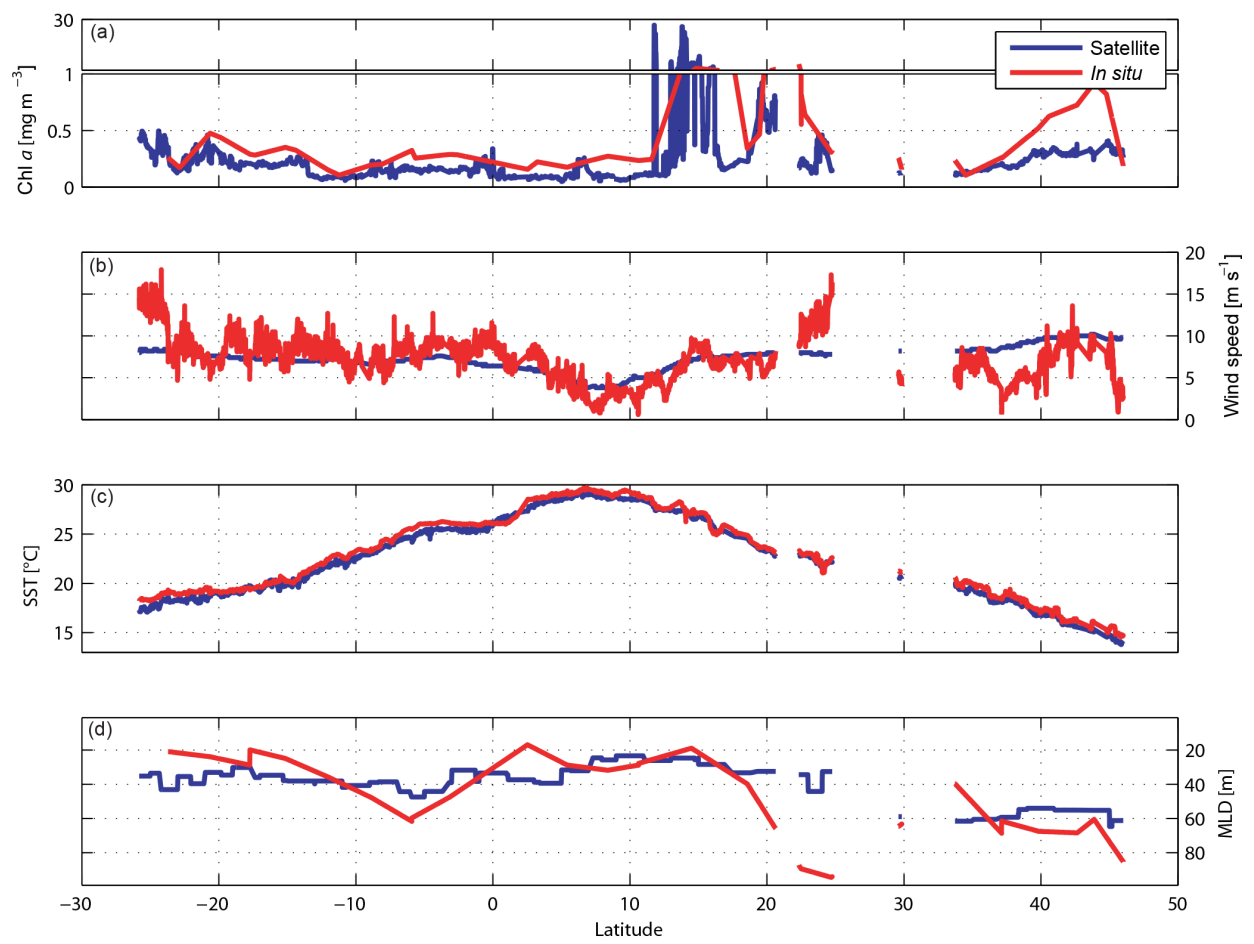

Figure 3. Satellite and in situ data for the ANT-XXV/1 cruise. Monthly mean satellite-derived data (blue) and in situ measurements (red) of (a) chl $a$, (b) wind speed, (c) SST, and (d) monthly mean climatology values (blue) and in situ measurements (red) of MLD. 


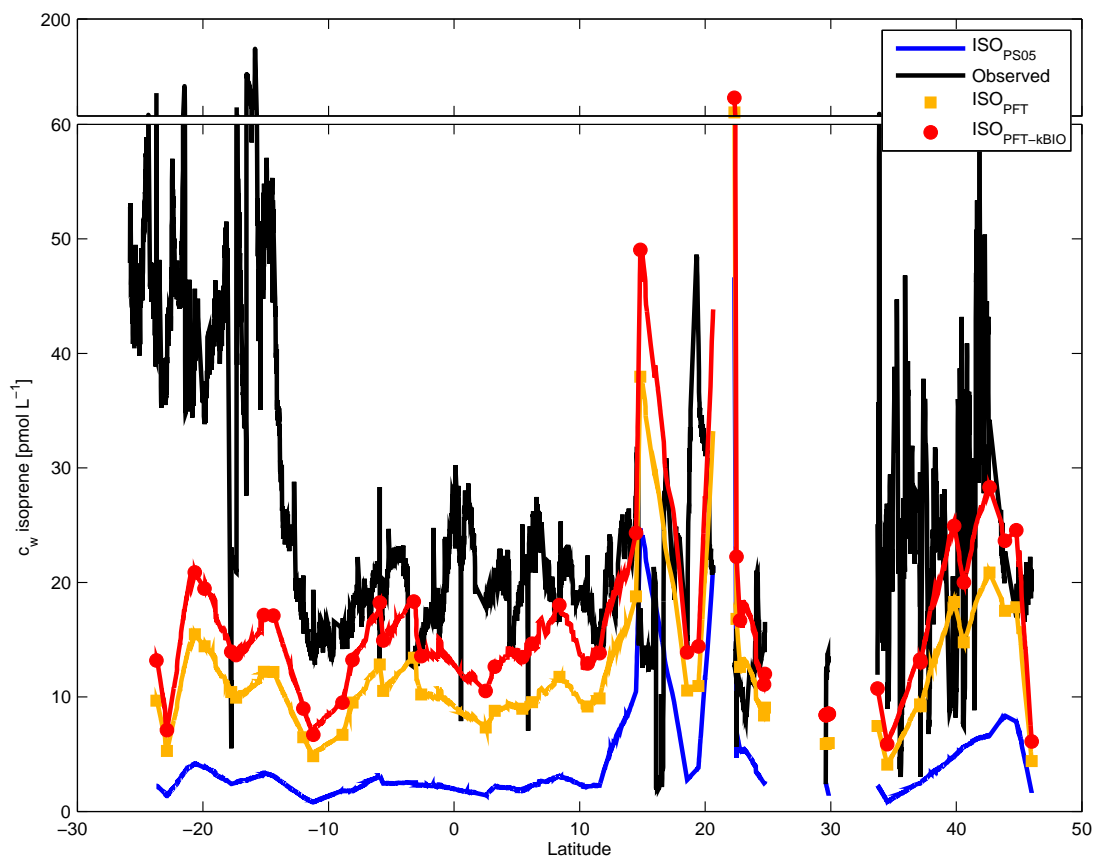

Figure 4. Comparison of in situ measured isoprene (black) with model-derived isoprene concentrations for the ANT-XXV/1 cruise using $\mathrm{ISO}_{\mathrm{PS} 05}$ (blue), ISO $\mathrm{PFT}_{\text {(orange), and ISO }} \mathrm{PFT}_{-k_{\mathrm{BIO}}}$ (red). Squares and circles indicate direct measurements; solid lines are interpolated data.

\subsection{Modeling isoprene production using PFTs and revised $k_{\mathrm{BIOL}}$}

Palmer and Shaw (2005) used a universal $P_{\text {chloro }}$ value of $1.8 \pm 0.7 \mu$ moles $(\mathrm{g} \mathrm{chl} a)^{-1}$ day $^{-1}$ based on laboratory phytoplankton monoculture experiments with several cyanobacteria, eukaryotes, and coccolithophores (Table 1; Shaw et al., 2003). Subsequent laboratory experiments with monocultures of different phytoplankton species have shown generally higher isoprene production rates with large variations between PFTs (Arnold et al., 2009; Bonsang et al., 2010; Colomb et al., 2008; Exton et al., 2013). In addition, Tran et al. (2013) observed that isoprene concentrations in the field are highly PFT dependent.

We averaged the $P_{\text {chloro values of different PFTs (Table 2) }}$ and multiplied these values by the amount of the corresponding PFT. Using PFTs instead of total biomass of phytoplankton ( $\mathrm{chl} a$ ) in the model run results in higher isoprene model concentrations (orange, Fig. 4), which match the overall isoprene concentration levels measured north of $10^{\circ} \mathrm{N}$ quite well. However, there are also regions where the model still cannot reproduce the measured isoprene concentrations. Between $10^{\circ} \mathrm{N}$ and $25^{\circ} \mathrm{S}$, the calculated isoprene concentrations are quite stable with only small variations between 6 and $23 \mathrm{pmol} \mathrm{L}^{-1}$. Measured concentrations are slightly higher between $10^{\circ} \mathrm{N}$ and $12^{\circ} \mathrm{S}(15-$ $30 \mathrm{pmol} \mathrm{L}^{-1}$ ) and sharply increase to $40-60 \mathrm{pmol} \mathrm{L}^{-1}$ south of $12^{\circ} \mathrm{S}$ with a maximum concentration of $150 \mathrm{pmol} \mathrm{L}^{-1}$ $\left(16^{\circ} \mathrm{S}\right)$. As there were no significant differences in wind speed, SST, or MLD in these two regions during the cruise, there must be at least one additional source which is not captured in the model. In contrast, at $15^{\circ} \mathrm{N}$ and at $22^{\circ} \mathrm{N}$ the model overestimates the isoprene concentration (Fig. 4). Chl $a$ concentrations are 10-20 times higher in these two areas than elsewhere on the cruise (Fig. 3) and dominated by diatoms. However, the calculated isoprene is not 10-20 times higher, since diatoms have a relatively low $P_{\text {chloro }}$ value $\left(2.54 \mu \mathrm{mol}(\mathrm{g} \mathrm{chl} a)^{-1} \mathrm{day}^{-1}\right)$ and, therefore, using their respective PFT value modulates the influence of the increased chl $a$ on isoprene concentrations (Fig. 5).

Excluding the two bloom areas, the main PFTs contributing to the modeled isoprene concentrations were prokaryotic phytoplankton (cyanobacteria and Prochlorococcus) and haptophytes (Fig. 5, see also Taylor et al., 2011a). It should be noted that the PFTs considered in our study are only part of the full phytoplankton community. In addition, these values can be easily over- or underestimated due to a high variability in the $P_{\text {chloro }}$ values within one group of PFTs (e.g., haptophytes: $1-15.36 \mu \mathrm{mol}$ isoprene $(\mathrm{g} \mathrm{chl} a)^{-1}$ day $^{-1}$; Table 2). Using the ISO ${ }_{\mathrm{PFT}-k_{\mathrm{BIO}}}$ model approach, the isoprene concentrations increase by a factor of 1.35 , resulting in better agreement with the observations (Fig. 4). Overall for the conditions of this cruise, the ISO $_{\mathrm{PFT}-k_{\mathrm{BIO}}}$ model simulation yields 12 -fold higher isoprene levels than ISOPS05 (mean error of $11.8 \mathrm{pmol} \mathrm{L}^{-1}$ ).

It is obvious that even after implementing these changes the model does not reproduce all the measured isoprene values or their distribution pattern. One particular problem is 
Table 2. Chlorophyll-normalized isoprene production rates $\left(P_{\text {chloro }}\right)$ determined from analysis of phytoplankton cultures experiments described in the literature (Exton et al., 2013 and references therein). $P_{\text {chloro }}$ values are given in $\mu m o l(\mathrm{~g} \mathrm{chl} a)^{-1} \mathrm{day}^{-1}$.

\begin{tabular}{|c|c|c|c|}
\hline Species & $\begin{array}{r}\text { Literature } \\
P_{\text {chloro value }}\end{array}$ & $\begin{array}{r}\text { Averaged } P_{\text {chloro values }} \\
\text { for specific PFTs }\end{array}$ & References \\
\hline \multicolumn{4}{|l|}{ Bacillariophyceae } \\
\hline Chaetoceros neogracilis (CCMP 1318) & 28.48 & \multirow{11}{*}{2.54} & Colomb et al. (2008) \\
\hline Chaetoceros neogracilis (CCMP 1318) & $1.26 \pm 1.19$ & & Bonsang et al. (2010) \\
\hline Thalassiosira pseudonana (CCAP 1085/12 & $5.76 \pm 0.24$ & & Exton et al. (2013) \\
\hline Pelagomonas calceolate (CCMP 1214) & $1.6 \pm 1.6$ & & Shaw et al. (2003) \\
\hline Phaeodactylum tricornutum (Falkowski) & 2.85 & & Colomb et al. (2008) \\
\hline Phaeodactylum tricornutum (UTEX 646) & $1.12 \pm 0.32$ & & Bonsang et al. (2010) \\
\hline Skeletonema costatum & $1.32 \pm 1.21$ & & Bonsang et al. (2010) \\
\hline Skeletonema costatum (CCMP 1332) & 1.8 & & Shaw et al. (2003) \\
\hline Thalassiosira weissflogii (CCMP 1051) & $4.56 \pm 0.24$ & & Exton et al. (2013) \\
\hline Diatoms (elsewhere) & $2.48 \pm 1.75$ & & Arnold et al. (2009) \\
\hline Cylindrotheca sp. & 2.64 & & Exton et al. (2013) \\
\hline \multicolumn{4}{|l|}{ cold adapted Bacillariophyceae } \\
\hline Fragilariopsis kerguelensis & $0.56 \pm 0.35$ & \multirow{7}{*}{$\begin{array}{r}\text { Excluded from the } \\
\text { average isoprene } \\
\text { production rate }\end{array}$} & Bonsang et al. (2010) \\
\hline Chaetoceros debilis & $0.65 \pm 0.2$ & & Bonsang et al. (2010) \\
\hline Chaetoceros muelleri (CCAP 1010/3) & $9.36 \pm 1.2$ & & Exton et al. (2013) \\
\hline Fragilariopsis cylindrus & $0.96 \pm 0.24$ & & Exton et al. (2013) \\
\hline Nitzschia sp. (CCMP 1088) & $0.96 \pm 0.24$ & & Exton et al. (2013) \\
\hline Synedropsis sp. (CCMP 2745) & $0.72 \pm 0.24$ & & Exton et al. (2013) \\
\hline Diatoms (Southern Ocean) & $1.21 \pm 0.57$ & & Arnold et al. (2009) \\
\hline \multicolumn{4}{|l|}{ Dinophyceae } \\
\hline Prorocentrum minimum & $10.08 \pm 1.44$ & \multirow{5}{*}{13.78} & Exton et al. (2013) \\
\hline Symbiodinium sp. (CCMP 2464) & $4.56 \pm 3.12$ & & Exton et al. (2013) \\
\hline Symbiodinium sp. (CCMP 2469) & $17.04 \pm 8.4$ & & Exton et al. (2013) \\
\hline Symbiodinium sp. & $9.6 \pm 2.8$ & & Exton et al. (2013) \\
\hline Symbiodinium sp. (CCMP 2463) & $27.6 \pm 1.68$ & & Exton et al. (2013) \\
\hline \multicolumn{4}{|l|}{ Cyanophyceae } \\
\hline Prochlorococcus sp. (axenic MED4) (high light) & $1.5 \pm 0.9$ & 1.5 & Shaw et al. (2003) \\
\hline Prochlorococcus & $9.66 \pm 5.78$ & 9.66 & Arnold et al. (2009) \\
\hline Synechococcus sp. (RCC 40) & $4.97 \pm 2.87$ & \multirow{3}{*}{6.04} & Bonsang et al. (2010) \\
\hline Synechococcus sp. (WH 8103) & 1.4 & & Shaw et al. (2003) \\
\hline Synechococcus sp. (CCMP 1334) & $11.76 \pm 0$ & & Exton et al. (2013) \\
\hline \multicolumn{4}{|l|}{ Chlorophyceae } \\
\hline Dunaliella tertiolecta & $0.36 \pm 0.22$ & \multirow{3}{*}{1.47} & Bonsang et al. (2010) \\
\hline Dunaliella tertiolecta (DUN, Falkowski) & 2.85 & & Colomb et al. (2008) \\
\hline Dunaliella tertiolecta (CCMP 1320) & 1.2 & & Exton et al. (2013) \\
\hline \multicolumn{4}{|l|}{ Cryptophyceae } \\
\hline Rhodomonas lacustris (CCAP 995/3) & $9.36 \pm 0.72$ & 9.36 & Exton et al. (2013) \\
\hline \multicolumn{4}{|l|}{ Prasinophyceae } \\
\hline Micromonas pusilla (CCMP 489) & $1.4 \pm 0.8$ & \multirow{3}{*}{12.47} & Shaw et al. (2003) \\
\hline Prasinococcus capsulatus (CCMP 1614) & $32.16 \pm 5.76$ & & Exton et al. (2013) \\
\hline Tetraselmis sp. (CCMP 965) & $3.84 \pm 0.24$ & & Exton et al. (2013) \\
\hline \multicolumn{4}{|l|}{ Prymnesiophyceae } \\
\hline Calcidiscus leptoporus (AC 365) & 5.4 & \multirow{7}{*}{6.92} & Colomb et al. (2008) \\
\hline Emiliania huxleyi (CCMP 371) & 11.54 & & Colomb et al. (2008) \\
\hline Emiliania huxleyi (CCMP 371) & 1 & & Bonsang et al. (2010) \\
\hline Emiliania huxleyi (CCMP 373) & $1 \pm 0.5$ & & Shaw et al. (2003) \\
\hline Emiliania huxleyi (CCMP 373) & $2.88 \pm 0.48$ & & Exton et al. (2013) \\
\hline Emiliania huxleyi (CCMP 1516) & $11.28 \pm 0.96$ & & Exton et al. (2013) \\
\hline Gephyrocapsa oceanica & $15.36 \pm 4.1$ & & Exton et al. (2013) \\
\hline
\end{tabular}




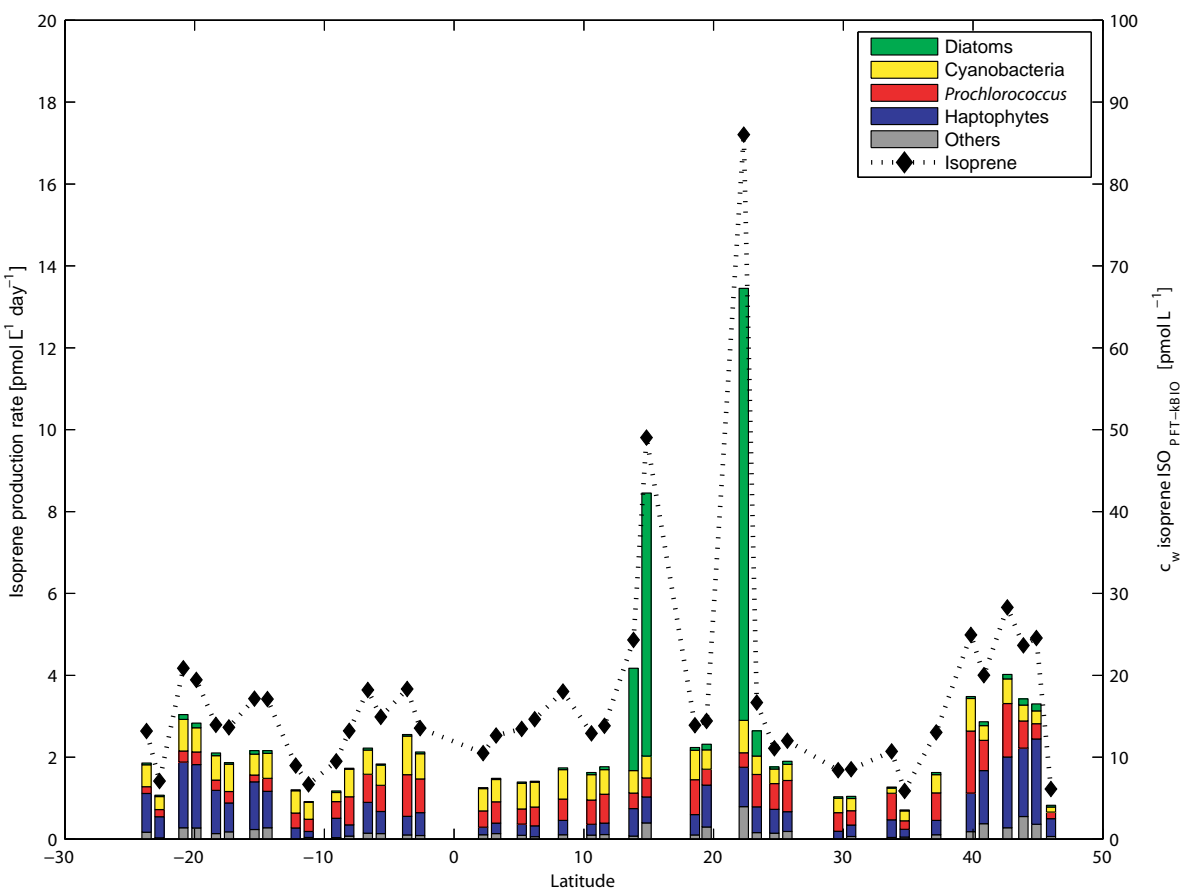

Figure 5. Proportion of main PFTs contributing to the total isoprene production rate for each station during ANT-XXV/1.

that marine isoprene emissions are very low in comparison to terrestrial isoprene emissions. Coastal emissions have to be calculated and interpreted carefully due to this terrestrial influence. We assume no terrestrial influence in the open ocean, since the atmospheric lifetime of isoprene is short. Despite the terrestrial influence on atmospheric isoprene values over the ocean, calculating surface ocean isoprene concentrations, other assumptions in the model should be scrutinized in order to understand the discrepancies between measured and calculated values:

1. The model assumes well-mixed isoprene concentrations through the MLD, which is, in fact, not the case. Measurements of depth profiles show a vertical gradient with a maximum of isoprene at the depth of the chl $a$ maximum slightly below the MLD (Bonsang et al., 1992; Milne et al., 1995; Moore and Wang, 2006), which was also measured during our three campaigns (data not shown). Gantt et al. (2009) tried to solve this problem using a light-dependent isoprene production rate, but this resulted in high fluxes in the tropics that are questionable when compared to field measurements.

2. Using PFT-dependent production rates strongly improved the model by adding more specific and realistic product information. Nonetheless, we may still be missing some important species within the PFTs, and the average taken over the isoprene measurements among the cultured species within one PFT carries some uncertainty. We used up to eight different PFTs, illustrating that only the four main groups (haptophytes, cyanobacteria, Prochlorococcus, and diatoms) produce the most isoprene (Fig. 5). These groups are also the only four detected by the satellite product PHYSAT (Alvain et al., 2005), which has been used previously for predictions of isoprene (Arnold et al., 2009; Gantt et al., 2009). However, neglecting the other PFTs might lead to different results (others, Fig. 5). This highlights the need to measure the isoprene emission of more species within each PFT group under different physiological conditions. Emissions in laboratory culture experiments can vary depending on the growth stage of the phytoplankton species (Milne et al., 1995). Shaw et al. (2003) showed that the health conditions of the phytoplankton species directly influence the emission rates of isoprene when using phage-infected cultures. However, also environmental stress factors, such as temperature and light, influence the ability of different species to produce isoprene (Shaw et al., 2003; Exton et al., 2013; Meskhidze et al., 2015). More exact data would also, potentially, lower the uncertainty of global marine isoprene emissions, which was found to be in the range of $20 \%$ when using the upper or lower bounds of PFTdependent production rates (Gantt et al., 2009).

3. The temporal resolution of the simple model may also not be adequate. Gantt et al. (2009) could show that their model, using remote sensing input in combination with the light dependence of isoprene production, overestimated daytime isoprene concentrations and underestimated nighttime concentrations compared to the high 
temporal resolution field measurements of Matsunaga et al. (2002). The possible diurnal cycle of isoprene could not be resolved with remote sensing data obtained only at a specific local time during the day (e.g., 10:00 for MODIS Terra and 13:00 for MODIS Aqua).

4. The role of bacteria in producing isoprene is also unclear and may be a missing variable in the steady-state equation. Alvarez et al. (2009) observed bacterial isoprene production in estuary sediments and discovered isoprene production using different cultures of bacteria. However, Shaw et al. (2003) could not find any evidence of bacterial isoprene production in separate experiments.

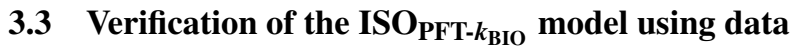 from the Indian and eastern Pacific Oceans}

Isoprene concentrations calculated with the original (ISOPS05) and revised (ISOPFT- $k_{\mathrm{BIO}}$ ) model are compared to measured isoprene in the surface ocean at two additional campaigns in two widely differing ocean basins (Indian Ocean, SPACES/OASIS, 2014; eastern Pacific Ocean, ASTRA-OMZ, 2015). The original model ISOPS05 predicts on average $19 \pm 12$ times lower isoprene concentrations compared with measured values for the additional two ship campaigns (circles, Fig. 6), which confirms the results obtained for ANT-XXV/1. With the newly determined (lower) value for $k_{\mathrm{BIOL}}$ and $\mathrm{PFT}$-dependent $P_{\text {chloro }}$ values, the

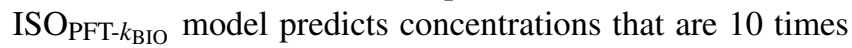
higher than the original model ISOPS05 output (crosses, Fig. 6). This leads to a mean underestimation of $1.7 \pm 1.2$ between modeled and measured isoprene concentrations. The main cause of the better agreement between measured and modeled isoprene concentrations is the isoprene production rate related to the production input parameter (color coding, Fig. 6). The mean isoprene production rate using chl $a$ as an input parameter multiplied by a factor of $1.8 \mu \mathrm{mol}(\mathrm{g} \mathrm{chl} a)^{-1}$ day $^{-1}$ is less than $0.5 \mathrm{pmol} \mathrm{L}^{-1} \mathrm{day}^{-1}$, which is insufficient to explain the measured concentrations in all three campaigns. Using $P_{\text {chloro }}$ values multiplied with the concentration of the related PFT yields in an isoprene production rate of $1-2 \mathrm{pmol} \mathrm{L}^{-1} \mathrm{day}^{-1}$ in non-bloom areas and even higher rates during phytoplankton blooms, resulting in isoprene concentrations that are comparable to the measured ones. The opposite can also occur, as seen on DOY 322 (Fig. 6), when PFT specific production rates are smaller than those using chl $a$ only, due to the dominance of a low isoprene-producing PFT. Even though the improved model is tested in three widely different ocean basins, there are still different regions where the model should be tested with direct isoprene measurements to verify the model output.

\section{Global oceanic isoprene emissions and implications for marine aerosol formation}

Monthly mean global ocean isoprene concentrations were calculated using the revised model ISO $_{\text {PFT- } k_{\mathrm{BIO}}}\left(2^{\circ} \times 2^{\circ}\right.$ grid). As there were no PFT satellite data readily available, we used an empirical relationship between chl $a$ and PFTs as parameterized by Hirata et al. (2011). The quality of this parameterization was verified against the PFT data sets from all three campaigns (coefficient of determination: $R^{2}=0.89$, Fig. S1 in the Supplement) and is shown in Fig. 6 (grey diamonds). Monthly mean global ocean isoprene emissions (Figs. S2-S13 in the Supplement) were averaged in order to compute global sea-to-air fluxes of isoprene for 2014 (Fig. 7). An annual emission of $0.21 \mathrm{Tg} C$ was calculated, which is 2 times higher than the value estimated by Palmer and Shaw (2005) (0.11 Tg $\left.\mathrm{C} \mathrm{yr}^{-1}\right)$. The highest emissions, more than $100 \mathrm{nmol} \mathrm{m}^{-2} \mathrm{day}^{-1}$, can be seen in the North Atlantic Ocean and the Southern Ocean, associated with high biological productivity and strong winds driving the air-sea gas exchange. The influence of regional hot spots of biological productivity, such as the upwelling off Mauretania or the Brazil-Malvinas Confluence Zone, can also be seen. The tropics $\left(23.5^{\circ} \mathrm{S}-23.5^{\circ} \mathrm{N}\right)$ account for only $28 \%$ of global isoprene emissions, but they represent $\sim 47 \%$ of the world oceans.

Yearly emissions of $0.21 \mathrm{TgC}$ are at the lower end of the range of previously published studies (Arnold et al., 2009, 0.27 $\mathrm{TgC} \mathrm{yr}^{-1}$; Gantt et al., 2009, 0.92 $\mathrm{TgC} \mathrm{yr}^{-1}$ ). Both studies use remotely sensed PFT data instead of chl $a$ to evaluate the isoprene production. Unlike this study, they implemented the Alvain et al. (2005) approach using PHYSAT data, which uses spectral information to produce global distributions of the dominant PFT but is limited to four phytoplankton groups (haptophytes, Prochlorococcus, Synechococcus, and diatoms). It should be noted that PHYSAT does not provide actual concentrations but rather only the relative dominance of the four groups. Arnold et al. (2009) used similar assumptions as Palmer and Shaw (2005) to calculate isoprene loss, namely that loss in the water column by advective mixing and aqueous oxidation is on a longer timescale than loss by air-sea gas exchange and, therefore, negligible. Thus, their calculated emissions of $0.27 \mathrm{Tg} \mathrm{C} \mathrm{yr}^{-1}$ are an upper estimate. The approach of Gantt et al. (2009) had two main differences compared to our study. (1) Instead of using the MLD climatology of de Boyer Montégut et al. (2004), they used a maximum depth where isoprene production can occur as calculated by the downwelling irradiance (using the diffuse attenuation coefficient values at $490 \mathrm{~nm}$ ) and the light propagation throughout the water column that is estimated by using the Lambert-Beer law. (2) They tested two of the detectable PFTs in laboratory experiments using monocultures of diatoms and coccolithophores growing under different light conditions to evaluate light-intensity-dependent isoprene production rates. Light-intensity-dependent production 

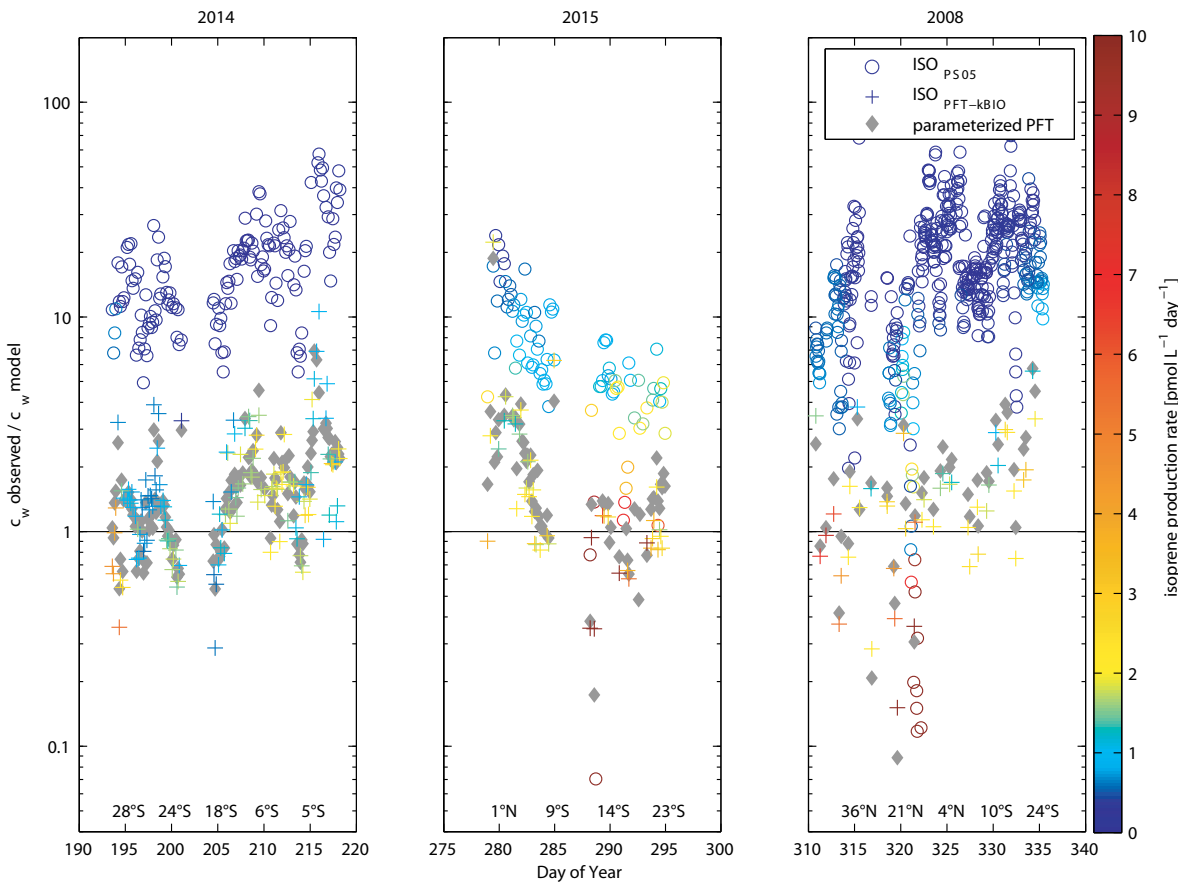

Figure 6. Observed isoprene concentration divided by modeled isoprene concentration on a logarithmic scale for three different cruises: on the left is SPACES/OASIS 2014, in the middle is ASTRA-OMZ 2015, and on the right is ANT-XXV/1 2008. Circles and crosses represent data derived by the original ISOPS05 and revised ISOPFT- $k_{\mathrm{BIO}}$ model, respectively. Every data point is color coded with the corresponding isoprene production rate input parameter. Grey diamonds represent data using parameterized PFT data by Hirata et al. (2011); the black line represents a ratio of 1 .

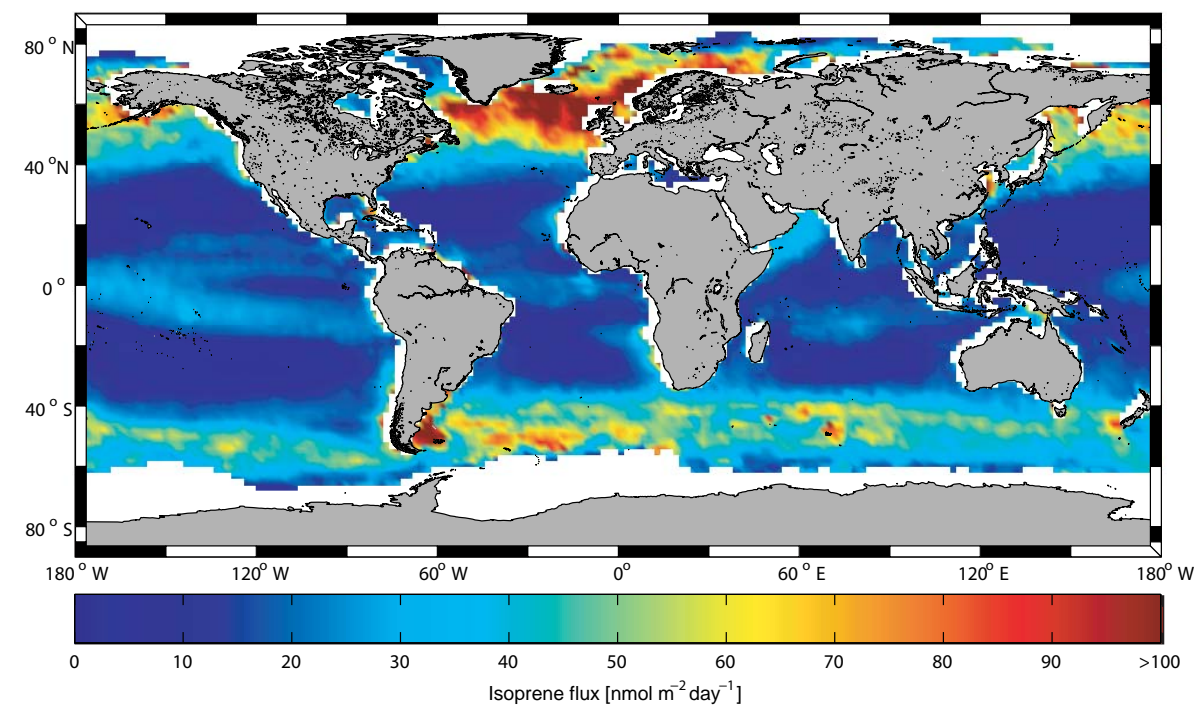

Figure 7. Global marine isoprene fluxes in $\mathrm{nmol} \mathrm{m}^{-2} \mathrm{day}^{-1}$ for 2014.

rates of Prochlorococcus and Synechococcus were derived after Gantt et al. (2009) using the original production rates at a specified wavelength measured by Shaw et al. (2003). Their isoprene emission calculations are more than 4 times higher than calculated with our approach, probably as a result of the light-dependent isoprene production rates. Whereas our global map shows very low emissions in the tropics due to a low phytoplankton productivity, the emissions modeled by Gantt et al. (2009) are comparable to those of high productivity areas like the Southern Ocean or the North Atlantic Ocean, likely as a consequence of the high solar radiation in the tropics. The data from our three cruises contradict this 


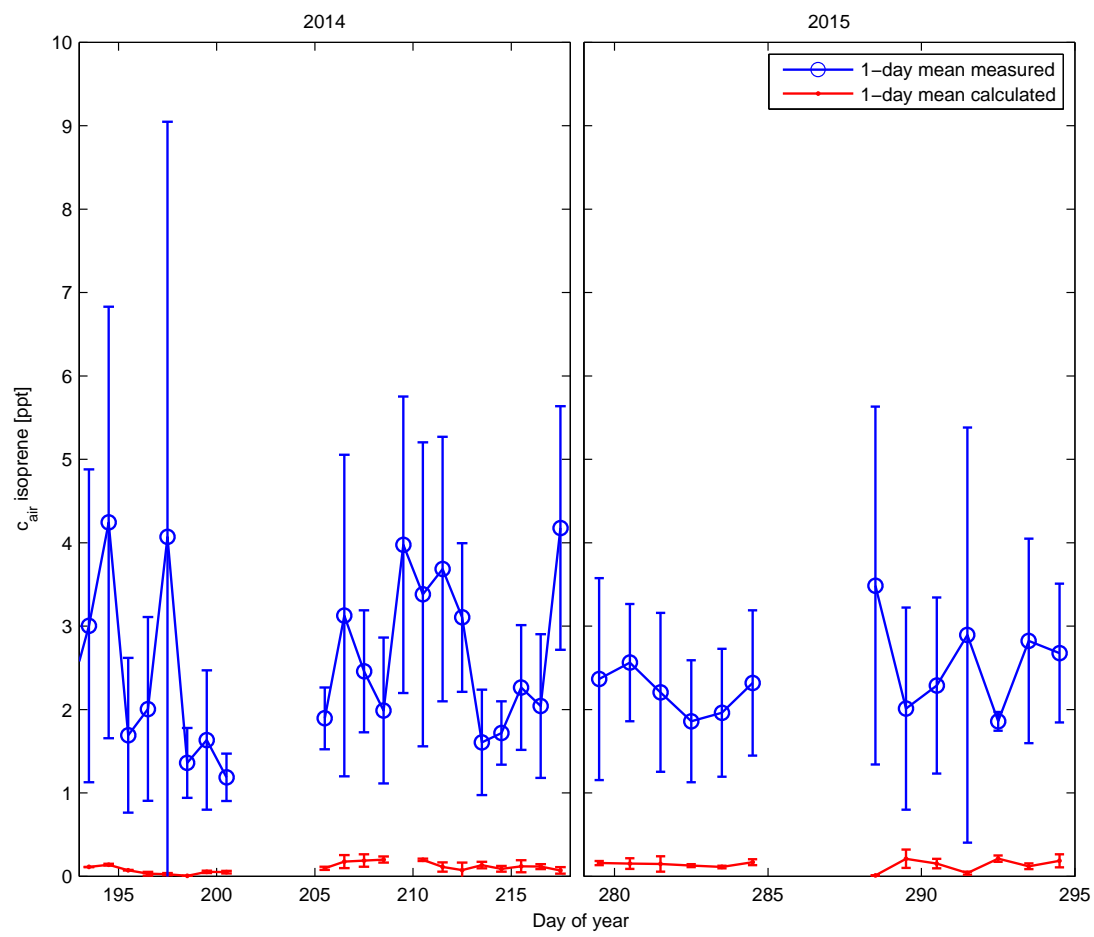

Figure 8. One-day mean measured (blue) and calculated (red) daytime isoprene mixing ratios (ppt) during SPACES/OASIS (2014) and ASTRA-OMZ (2015). Calculated isoprene air values were derived by using the sea-to-air flux, a marine boundary layer height of $800 \mathrm{~m}$, and the $1 \mathrm{~h}$ atmospheric lifetime based on a simple box model approach for each individual measurement.

model-derived result and show very low concentrations in the tropical regions, which implies a very low flux of isoprene to the atmosphere. Furthermore, Meskhidze et al. (2015) showed that, at a specific light intensity, the isoprene production rate of tested monocultures sharply decreases.

Using atmospheric isoprene concentrations measured in two of the three campaigns, we were able to use a top-down approach to calculate isoprene emissions in order to compare with the bottom-up flux estimates. We used a box model with an assumed marine boundary layer height (MBLH) of $800 \mathrm{~m}$, which reflected the local conditions during the two campaigns. The only source of isoprene for the air was assumed to be the sea-to-air flux (emission) and the atmospheric lifetime $(\tau)$ was assumed to be determined by reaction with $\mathrm{OH}$ (chemical loss, $1 \mathrm{~h}$ ). The sea-to-air flux was calculated by multiplying $k_{\mathrm{AS}}$ with the measured isoprene concentration $\left(C_{\mathrm{W}}\right)$ in the ocean (Eq. 3$)$. We assumed $C_{\mathrm{A}}$ to be zero in order to have the highest possible sea-to-airflux, following a conservative approach. The concentration outside the box was assumed to be the same as inside to neglect advection into and out of the box. The resulting calculated steady-state isoprene air concentration for every box (1day mean value of all individual measurements at daytime) is shown in Fig. 8 (for a $1 \mathrm{~h}$ lifetime it takes approximately $10 \mathrm{~h}$ to achieve steady state) and is calculated as follows:
$C_{\mathrm{A}}=\left(k_{\mathrm{AS}} \times C_{\mathrm{W}}\right) \frac{\tau}{\mathrm{MBLH}}$.

For comparison, the mean measured concentration of isoprene in the atmosphere during the two cruises is $2.5 \pm 1.5 \mathrm{ppt}$ and therefore 45 times higher than the calculated isoprene air values. The measured concentrations match previously measured remote open ocean atmospheric values (Shaw et al., 2003). We only used atmospheric measurements which were obtained during daytime (to reflect reaction with $\mathrm{OH}$ ) and were not influenced by terrestrial sources. This was determined by omitting data points with concomitant high levels of anthropogenic hydrocarbons (concentrations of butane higher $20 \mathrm{ppt}$ ). Reported mean atmospheric lifetime estimates of isoprene range from minutes up to $4 \mathrm{~h}$, depending mainly on the atmospheric concentration of $\mathrm{OH}$ (Pfister et al., 2008). We calculate that for an estimated lifetime of 1 and $4 \mathrm{~h}$, a sea-to-air flux of at least 2000 and $500 \mathrm{nmol} \mathrm{m}^{-2}$ day $^{-1}$, respectively, is needed to reach the atmospheric concentration measured during SPACES/OASIS and ASTRA-OMZ, which is approximately 10-20 times higher than computed (even when assuming $C_{\mathrm{A}}$ as zero). Recent studies showed that the measured fluxes of isoprene range from $4.6-148 \mathrm{nmol} \mathrm{m}^{-2}$ day $^{-1}$ in June-July 2010 in the Arctic (Tran et al., 2013) to 181.0$313.1 \mathrm{nmol} \mathrm{m}^{-2}$ day $^{-1}$ in the productive Southern Ocean 
during austral summer 2010/2011 (Kameyama et al., 2014). Despite these high literature values, it appears that the calculated fluxes cannot explain the measured atmospheric concentrations even when a conservative lifetime of $4 \mathrm{~h}$ is assumed.

\section{Conclusions}

The revised Palmer and Shaw (2005) isoprene emission model was evaluated against direct surface ocean isoprene measurements from three different ocean basins, yielding comparable ocean concentrations that were slightly underestimated (factor of $1.7 \pm 1.2$ ). The resulting annual global oceanic isoprene emissions are 2 times higher than the calculated flux with the original model. However, using a simple top-down approach based on measured atmospheric isoprene levels, we calculate that emissions from the ocean are required to be more than 1 order of magnitude greater than those computed using the bottom-up estimate based on measured oceanic isoprene levels. This result is consistent with a numerical evaluation of global ocean isoprene emissions by Luo and $\mathrm{Yu}$ (2010). One possible explanation could be production in the surface microlayer (SML) that is not simulated by the model. Ciuraru et al. (2015) showed that isoprene is produced photochemically by surfactants in an organic monolayer at the air-sea interface. As the SML is enriched with surfactants (Wurl et al., 2011), the isoprene flux from the SML could range from 1000 to $33000 \mathrm{nmol} \mathrm{m}^{-2}$ day $^{-1}$, which is much larger (about 2 orders of magnitude) than the highest fluxes calculated from our observations. To date, there is no evidence of such a large gradient in the surface ocean between the surface and $10 \mathrm{~m}$. Thus, further field measurements probing the SML could be a step forward in reconciling the role of the ocean for the atmospheric isoprene budget. Using the bottom-up approach, isoprene emissions are much smaller and given this scenario, isoprene consequently appears to be a relatively insignificant source of OC in the remote marine atmosphere. Arnold et al. (2009) calculated a yield of $0.04 \mathrm{Tg} \mathrm{yr}^{-1} \mathrm{OC}$ derived from marine isoprene by using yearly emissions of $1.9 \mathrm{Tg} \mathrm{yr}^{-1}$ and a SOA yield of $2 \%$ (Henze and Seinfeld, 2006). This is equivalent to $0.5 \%$ of estimated $8 \mathrm{Tg} \mathrm{yr}^{-1}$ global source of oceanic OC (Spracklen et al., 2008). Using our bottom-up emission of $0.21 \mathrm{Tg} \mathrm{C} \mathrm{yr}^{-1}$ will even lower this small influence. Until this discrepancy between bottom-up and top-down approaches is resolved, the question of whether isoprene is a main precursor to remote marine boundary layer particle formation still remains open.

\section{Data availability}

All isoprene data are available from the corresponding author. Pigment data from ANT-XXV/1 are available from PANGAEA (Taylor et al., 2011b). Pigment data from SPACES/OASIS and ASTRA-OMZ will be available from
PANGAEA but for now can be obtained through the corresponding author.

\section{The Supplement related to this article is available online at doi:10.5194/acp-16-11807-2016-supplement.}

Acknowledgements. The authors would like to thank the captain and crew of the R/V Polarstern (ANT-XXV/1) and R/V Sonne (SPACES/OASIS and ASTRA-OMZ) as well as the chief scientists, Gerhard Kattner (ANT-XXV/1) and Kirstin Krüger (SPACES/OASIS). Boris Koch and Birgit Quack also provided valuable help. We thank Sonja Wiegmann for HPLC pigment analysis of SPACES/OASIS and ASTRA-OMZ samples, Sonja Wiegmann and Wee Cheah for pigment sampling during SPACES/OASIS, and Rüdiger Röttgers for helping with pigment sampling during ASTRA-OMZ. Paul I. Palmer gratefully acknowledges his Royal Society Wolfson Research Merit Award. Elliot Atlas acknowledges support from the NASA UARP program and thanks Leslie Pope and Xiaorong Zhu for assistance in canister preparation. The authors gratefully acknowledge the NOAA Air Resources Laboratory (ARL) for the provision of the HYSPLIT transport and dispersion model used in this publication as well as NASA for providing the satellite MODIS Aqua and MODIS Terra data. QuikScat and SeaWinds data were produced by Remote Sensing Systems with thanks to the NASA Ocean Vector Winds Science Team for funding and support. This work was carried out under the Helmholtz Young Investigator Group of Christa A. Marandino, TRASE-EC (VH-NG-819), from the Helmholtz Association through the President's Initiative and Networking Fund and the GEOMAR Helmholtz Centre for Ocean Research Kiel. The R/V Sonne cruises SPACES/OASIS and ASTRA-OMZ were financed by the BMBF through grants 03G0235A and 03G0243A, respectively.

The article processing charges for this open-access publication were covered by a Research Centre of the Helmholtz Association.

Edited by: A. Hofzumahaus

Reviewed by: two anonymous referees

\section{References}

Aiken, J., Pradhan, Y., Barlow, R., Lavender, S., Poulton, A., Holligan, P., and Hardman-Mountford, N.: Phytoplankton pigments and functional types in the Atlantic Ocean: A decadal assessment, 1995-2005, Deep-Sea Res. Pt. II, 56, 899-917, doi:10.1016/j.dsr2.2008.09.017, 2009.

Alvain, S., Moulin, C., Dandonneau, Y., and Breon, F. M.: Remote sensing of phytoplankton groups in case 1 waters from global SeaWiFS imagery, Deep-Sea Res. Pt. I, 52, 1989-2004, doi:10.1016/j.dsr.2005.06.015, 2005.

Alvarez, L. A., Exton, D. A., Timmis, K. N., Suggett, D. J., and McGenity, T. J.: Characterization of marine isoprene- 
degrading communities, Environ. Microbiol., 11, 3280-3291, doi:10.1111/j.1462-2920.2009.02069.x, 2009.

Andreae, M. O. and Rosenfeld, D.: Aerosol-cloudprecipitation interactions. Part 1. The nature and sources of cloud-active aerosols, Earth-Sci. Rev., 89, 13-41, doi:10.1016/j.earscirev.2008.03.001, 2008.

Anttila, T., Langmann, B., Varghese, S., and O'Dowd, C.: Contribution of Isoprene Oxidation Products to Marine Aerosol over the North-East Atlantic, Advances in Meteorology, 2010, 482603, doi:10.1155/2010/482603, 2010.

Arneth, A., Monson, R. K., Schurgers, G., Niinemets, Ü., and Palmer, P. I.: Why are estimates of global terrestrial isoprene emissions so similar (and why is this not so for monoterpenes)?, Atmos. Chem. Phys., 8, 4605-4620, doi:10.5194/acp-8-46052008, 2008.

Arnold, S. R., Spracklen, D. V., Williams, J., Yassaa, N., Sciare, J., Bonsang, B., Gros, V., Peeken, I., Lewis, A. C., Alvain, S., and Moulin, C.: Evaluation of the global oceanic isoprene source and its impacts on marine organic carbon aerosol, Atmos. Chem. Phys., 9, 1253-1262, doi:10.5194/acp-9-1253-2009, 2009.

Atkinson, R. and Arey, J.: Atmospheric degradation of volatile organic compounds, Chem. Rev., 103, 4605-4638, 2003.

Baker, A. R., Turner, S. M., Broadgate, W. J., Thompson, A., McFiggans, G. B., Vesperini, O., Nightingale, P. D., Liss, P. S., and Jickells, T. D.: Distribution and sea-air fluxes of biogenic trace gases in the eastern Atlantic Ocean, Global Biogeochem. Cy., 14, 871-886, doi:10.1029/1999gb001219, 2000.

Barlow, R. G., Cummings, D. G., and Gibb, S. W.: Improved resolution of mono- and divinyl chlorophylls $a$ and $b$ and zeaxanthin and lutein in phytoplankton extracts using reverse phase C-8 HPLC, Mar. Ecol.-Prog. Ser., 161, 303-307, doi:10.3354/meps 161303, 1997.

Bonsang, B., Polle, C., and Lambert, G.: Evidence for Marine Production of Isoprene, Geophys. Res. Lett., 19, 1129-1132, doi:10.1029/92gl00083, 1992.

Bonsang, B., Gros, V., Peeken, I., Yassaa, N., Bluhm, K., Zoellner, E., Sarda-Esteve, R., and Williams, J.: Isoprene emission from phytoplankton monocultures: the relationship with chlorophyll $a$, cell volume and carbon content, Environ. Chem., 7, 554-563, doi:10.1071/EN09156, 2010.

Broadgate, W. J., Liss, P. S., and Penkett, S. A.: Seasonal emissions of isoprene and other reactive hydrocarbon gases from the ocean, Geophys. Res. Lett., 24, 2675-2678, doi:10.1029/97g102736, 1997.

Broadgate, W. J., Malin, G., Kupper, F. C., Thompson, A., and Liss, P. S.: Isoprene and other non-methane hydrocarbons from seaweeds: a source of reactive hydrocarbons to the atmosphere, Mar. Chem., 88, 61-73, doi:10.1016/j.marchem.2004.03.002, 2004.

Carlton, A. G., Wiedinmyer, C., and Kroll, J. H.: A review of Secondary Organic Aerosol (SOA) formation from isoprene, Atmos. Chem. Phys., 9, 4987-5005, doi:10.5194/acp-9-4987-2009, 2009.

Charlson, R. J., Lovelock, J. E., Andreae, M. O., and Warren, S. G.: Oceanic phytoplankton, atmospheric sulfur, cloud albedo and climate, Nature, 326, 655-661, doi:10.1038/326655a0, 1987.

Ciuraru, R., Fine, L., Pinxteren, M. V., D’Anna, B., Herrmann, H., and George, C.: Unravelling New Processes at Interfaces: Photochemical Isoprene Production at the Sea Surface, Environ. Sci. Technol., 49, 13199-13205, doi:10.1021/acs.est.5b02388, 2015.
Colomb, A., Yassaa, N., Williams, J., Peeken, I., and Lochte, K.: Screening volatile organic compounds (VOCs) emissions from five marine phytoplankton species by head space gas chromatography/mass spectrometry (HS-GC/MS), J. Environ. Monitor., 10, 325-330, doi:10.1039/b715312k, 2008.

de Boyer Montégut, C., Madec, G., Fischer, A. S., Lazar, A., and Iudicone, D.: Mixed layer depth over the global ocean: An examination of profile data and a profile-based climatology, J. Geophys. Res.-Oceans, 109, C12003, doi:10.1029/2004JC002378, 2004.

de Leeuw, G., Andreas, E. L., Anguelova, M. D., Fairall, C. W., Lewis, E. R., O'Dowd, C., Schulz, M., and Schwartz, S. E.: Production flux of sea spray aerosol, Rev. Geophys., 49, RG2001, doi:10.1029/2010RG000349, 2011.

Ekström, S., Nozière, B., and Hansson, H.-C.: The Cloud Condensation Nuclei $(\mathrm{CCN})$ properties of 2-methyltetrols and C3C6 polyols from osmolality and surface tension measurements, Atmos. Chem. Phys., 9, 973-980, doi:10.5194/acp-9-973-2009, 2009.

Exton, D. A., Suggett, D. J., McGenity, T. J., and Steinke, M.: Chlorophyll-normalized isoprene production in laboratory cultures of marine microalgae and implications for global models, Limnol. Oceanogr., 58, 1301-1311, 2013.

Gantt, B., Meskhidze, N., and Kamykowski, D.: A new physicallybased quantification of marine isoprene and primary organic aerosol emissions, Atmos. Chem. Phys., 9, 4915-4927, doi:10.5194/acp-9-4915-2009, 2009.

Guenther, A., Karl, T., Harley, P., Wiedinmyer, C., Palmer, P. I., and Geron, C.: Estimates of global terrestrial isoprene emissions using MEGAN (Model of Emissions of Gases and Aerosols from Nature), Atmos. Chem. Phys., 6, 3181-3210, doi:10.5194/acp-63181-2006, 2006.

Henze, D. K. and Seinfeld, J. H.: Global secondary organic aerosol from isoprene oxidation, Geophys. Res. Lett., 33, L09812, doi:10.1029/2006g1025976, 2006.

Hirata, T., Hardman-Mountford, N. J., Brewin, R. J. W., Aiken, J., Barlow, R., Suzuki, K., Isada, T., Howell, E., Hashioka, T., Noguchi-Aita, M., and Yamanaka, Y.: Synoptic relationships between surface Chlorophyll $a$ and diagnostic pigments specific to phytoplankton functional types, Biogeosciences, 8, 311-327, doi:10.5194/bg-8-311-2011, 2011.

Hu, Q.-H., Xie, Z.-Q., Wang, X.-M., Kang, H., He, Q.-F., and Zhang, P.: Secondary organic aerosols over oceans via oxidation of isoprene and monoterpenes from Arctic to Antarctic, Supplement, Scientific Reports, 3, 2280, doi:10.1038/srep02280, 2013.

Kameyama, S., Yoshida, S., Tanimoto, H., Inomata, S., Suzuki, K., and Yoshikawa-Inoue, H.: High-resolution observations of dissolved isoprene in surface seawater in the Southern Ocean during austral summer 2010-2011, J. Oceanogr., 70, 225-239, doi:10.1007/s10872-014-0226-8, 2014.

Lana, A., Simó, R., Vallina, S. M., and Dachs, J.: Potential for a biogenic influence on cloud microphysics over the ocean: a correlation study with satellite-derived data, Atmos. Chem. Phys., 12, 7977-7993, doi:10.5194/acp-12-7977-2012, 2012.

Lelieveld, J., Butler, T. M., Crowley, J. N., Dillon, T. J., Fischer, H., Ganzeveld, L., Harder, H., Lawrence, M. G., Martinez, M., Taraborrelli, D., and Williams, J.: Atmospheric oxidation capacity sustained by a tropical forest, Supplement, Nature, 452, 737740, doi:10.1038/nature06870, 2008. 
Luo, G. and Yu, F.: A numerical evaluation of global oceanic emissions of a-pinene and isoprene, Atmos. Chem. Phys., 10, $2007-$ 2015, doi:10.5194/acp-10-2007-2010, 2010.

Matsunaga, S., Mochida, M., Saito, T., and Kawamura, K.: In situ measurement of isoprene in the marine air and surface seawater from the western North Pacific, Atmos. Environ., 36, 6051-6057, doi:10.1016/s1352-2310(02)00657-x, 2002.

Meskhidze, N., Sabolis, A., Reed, R., and Kamykowski, D.: Quantifying environmental stress-induced emissions of algal isoprene and monoterpenes using laboratory measurements, Biogeosciences, 12, 637-651, doi:10.5194/bg-12-637-2015, 2015.

Milne, P. J., Riemer, D. D., Zika, R. G., and Brand, L. E.: Measurement of Vertical-Distribution of Isoprene in Surface Seawater, Its Chemical Fate, and Its Emission from Several Phytoplankton Monocultures, Mar. Chem., 48, 237-244, doi:10.1016/03044203(94)00059-M, 1995.

Moore, R. M. and Wang, L.: The influence of iron fertilization on the fluxes of methyl halides and isoprene from ocean to atmosphere in the SERIES experiment, Deep-Sea Res. Pt. II, 53, 2398-2409, doi:10.1016/j.dsr2.2006.05.025, 2006.

Myriokefalitakis, S., Vignati, E., Tsigaridis, K., Papadimas, C., Sciare, J., Mihalopoulos, N., Facchini, M. C., Rinaldi, M., Dentener, F. J., Ceburnis, D., Hatzianastasiou, N., O’Dowd, C. D., van Weele, M., and Kanakidou, M.: Global Modeling of the Oceanic Source of Organic Aerosols, Advances in Meteorology, 2010, 939171, doi:10.1155/2010/939171, 2010.

O’Dowd, C. D., Langmann, B., Varghese, S., Scannell, C., Ceburnis, D., and Facchini, M. C.: A combined organic-inorganic sea-spray source function, Geophys. Res. Lett., 35, L01801, doi:10.1029/2007GL030331, 2008.

Ooki, A., Nomura, D., Nishino, S., Kikuchi, T., and Yokouchi, Y.: A global-scale map of isoprene and volatile organic iodine in surface seawater of the Arctic, Northwest Pacific, Indian, and Southern Oceans, J. Geophys. Res.-Oceans, 120, 4108-4128, doi:10.1002/2014JC010519, 2015.

Palmer, P. I. and Shaw, S. L.: Quantifying global marine isoprene fluxes using MODIS chlorophyll observations, Geophys. Res. Lett., 32, L09805, doi:10.1029/2005gl022592, 2005.

Pfister, G. G., Emmons, L. K., Hess, P. G., Lamarque, J. F., Orlando, J. J., Walters, S., Guenther, A., Palmer, P. I., and Lawrence, P. J.: Contribution of isoprene to chemical budgets: A model tracer study with the NCAR CTM MOZART-4, J. Geophys. Res.-Atmos., 113, D05308, doi:10.1029/2007JD008948, 2008.

Quinn, P. K. and Bates, T. S.: The case against climate regulation via oceanic phytoplankton sulphur emissions, Nature, 480, 5156, doi:10.1038/nature10580, 2011.

Shaw, S. L., Chisholm, S. W., and Prinn, R. G.: Isoprene production by Prochlorococcus, a marine cyanobacterium, and other phytoplankton, Mar. Chem., 80, 227-245, doi:10.1016/S03044203(02)00101-9, 2003

Shaw, S. L., Gantt, B., and Meskhidze, N.: Production and Emissions of Marine Isoprene and Monoterpenes: A Review, Advances in Meteorology, doi:10.1155/2010/408696, 2010.

Spracklen, D. V., Arnold, S. R., Sciare, J., Carslaw, K. S., and Pio, C.: Globally significant oceanic source of organic carbon aerosol, Geophys. Res. Lett., 35, L12811, doi:10.1029/2008g1033359, 2008.
Taylor, B. B., Torrecilla, E., Bernhardt, A., Taylor, M. H., Peeken, I., Röttgers, R., Piera, J., and Bracher, A.: Bio-optical provinces in the eastern Atlantic Ocean and their biogeographical relevance, Biogeosciences, 8, 3609-3629, doi:10.5194/bg-8-36092011, 2011a.

Taylor, B. B., Torrecilla, E., Bernhardt, A., Taylor, M. H., Peeken, I., Röttgers, R., Piera, J., Bracher, A.: Pigments of phytoplankton during POLARSTERN cruise ANT-XXV/1, doi:10.1594/PANGAEA.819070, 2011b.

Tokarczyk, R., Goodwin, K. D., and Saltzman, E. S.: Methyl chloride and methyl bromide degradation in the Southern Ocean, Geophys. Res. Lett., 30, 1808, doi:10.1029/2003GL017459, 2003.

Tran, S., Bonsang, B., Gros, V., Peeken, I., Sarda-Esteve, R., Bernhardt, A., and Belviso, S.: A survey of carbon monoxide and nonmethane hydrocarbons in the Arctic Ocean during summer 2010, Biogeosciences, 10, 1909-1935, doi:10.5194/bg-10-1909-2013, 2013.

Twomey, S.: Pollution and planetary albedo, Atmos. Environ., 8, 1251-1256, doi:10.1016/0004-6981(74)90004-3, 1974.

Uitz, J., Claustre, H., Morel, A., and Hooker, S. B.: Vertical distribution of phytoplankton communities in open ocean: An assessment based on surface chlorophyll, J. Geophys. Res.-Oceans, 111, C08005, doi:10.1029/2005JC003207, 2006.

Vidussi, F., Claustre, H., Manca, B. B., Luchetta, A., and Marty, J.-C.: Phytoplankton pigment distribution in relation to upper thermocline circulation in the eastern Mediterranean Sea during winter, J. Geophys. Res.-Oceans, 106, 19939-19956, doi:10.1029/1999JC000308, 2001.

Wanninkhof, R.: Relationship between wind speed and gas exchange over the ocean, J. Geophys. Res.-Oceans, 97, 7373-7382, doi:10.1029/92JC00188, 1992.

Wurl, O., Wurl, E., Miller, L., Johnson, K., and Vagle, S.: Formation and global distribution of sea-surface microlayers, Biogeosciences, 8, 121-135, doi:10.5194/bg-8-121-2011, 2011.

Yassaa, N., Peeken, I., Zöllner, E., Bluhm, K., Arnold, S., Spracklen, D., and Williams, J.: Evidence for marine production of monoterpenes, Environ. Chem., 5, 391-401, doi:10.1071/EN08047, 2008.

Yokouchi, Y., Li, H. J., Machida, T., Aoki, S., and Akimoto, H.: Isoprene in the marine boundary layer (Southeast Asian Sea, eastern Indian Ocean, and Southern Ocean): Comparison with dimethyl sulfide and bromoform, J. Geophys. Res.-Atmos., 104, 80678076, doi:10.1029/1998jd100013, 1999.

Yvon-Lewis, S. A., Butler, J. H., Saltzman, E. S., Matrai, P. A., King, D. B., Tokarczyk, R., Moore, R. M., and Zhang, J.-Z.: Methyl bromide cycling in a warm-core eddy of the North Atlantic Ocean, Global Biogeochem. Cy., 16, 1141, doi:10.1029/2002GB001898, 2002.

Zindler, C., Marandino, C. A., Bange, H. W., Schütte, F., and Saltzman, E. S.: Nutrient availability determines dimethyl sulfide and isoprene distribution in the eastern Atlantic Ocean, Geophys. Res. Lett., 41, 3181-3188, doi:10.1002/2014GL059547, 2014. 